$\mathrm{A} \mathrm{J}_{\mathrm{ass}} \mathrm{H}$

Article history :

Received : 01.04.2014

Revised : 20.09.2014

Accepted : 06.10.2014

Members of the Research Forum

Associated Authors:

Department of Fruit Science, Punjab Agricultural University, LUDHIANA (PUNJAB) INDIA
Author for correspondence : P.P.S. GILL

Department of Fruit Science, Punjab Agricultural University, LUDHIANA (PUNJAB) INDIA

Email : parmpalgill@pau.edu
THE ASIAN JOURNAL OF HORTICULTURE

Volume 9 | Issue 2 | Dec., 2014 |301-304

Visit us -www.researchjournal.co.in

\title{
Effect of different stionic combinations on fruiting and quality of pear cV. PUNJAB BEAUTY
}

\section{P.P.S. GILL AND NAV PREM SINGH ${ }^{1}$}

ABSTRACT : The rootstock and/or inter-stock, and in particular their union with the scion, bring about their effects upon the scion by influencing the endogenous hormones, water and mineral elements within the plant. Hence, the effect of various rootstocks and interstocks on growth, fruiting and quality of semi-soft pear cv. PUNJAB BEAUTY was evaluated at Punjab Agricultural University, Ludhiana during the year 2013. The results show great variability among different stionic combinations. Double combination of Patharnakh cutting/Punjab Beauty resulted maximum plant height while minimum growth was observed in $\mathrm{T}_{10}$ (Patharnakh cutting/ Patharnakh/ Punjab Beauty) treatment. Rootstock and interstock girth was maximum in $T_{5}$ (Kainth large fruited/ Sucker/ Punjab Beauty) treatment while $\mathrm{T}_{10}$ combination recorded lowest values of rootstock and interstock girth. Similarly, scion girth of Punjab Beauty pear was maximum when Kainth small fruited was used as rootstock. The fruit number and yield per plant were recorded highest in $\mathrm{T}_{5}$ treatment while $\mathrm{T}_{15}$ combination resulted lowest yield. The fruit weight was maximum from double stoinic combination of Shiara/Punjab Beauty. The fruits from stionic combination of Sucker/ Sucker/ Punjab Beauty were softer, while $\mathrm{T}_{4}$ treatment resulted maximum fruit firmness. Double combination of Kainth small fruited/ Punjab Beauty resulted maximum TSS contents of fruits while the acid content remain unaffected by any treatment.

KEY WORDS : Rootstock, Interstock, Pear, Yield, Quality

HOW TO CITE THIS ARTICLE : Gill, P.P.S. and Singh, Nav Prem (2014). Effect of different stionic combinations on fruiting and quality of pear cv. PUNJAB BEAUTY. Asian J. Hort., 9(2) : 301-304. 